17. Central State Archives-Museum of Literature and Art of Ukraine Kyiv, F. 122 Donets-Tesseyr M. E. (1954-1957) Op. 1. Spr. 337. Savings Book of Gladkova Maria Eduardivna [in Russian].

18. Central State Archives-Museum of Literature and Art of Ukraine Kyiv, F. 122 Donets-Tesseyr M. E. (1954-1957) Op. 1. Spr. 396. Photos of the family members of Alexander Leonidovich Gladkov (1 husband M. E. Tesseyr): his father - Leonid Mikhailovich Gladkov, mother - Julia Ivanivna Gladkova, first wife - BertaBlyansh Gladkova (born in Komb).

19. Central State Archives-Museum of Literature and Art of Ukraine Kyiv, F. 122 Donets-Tesseyr M. E. (1954-1957) Op. 1. Spr. 409. Metric certificate of O. L. Gladkov, first husband M. E. Tessier [in Russian].

20. Central State Historical Archive of Ukraine, Kyiv. F 127 Kyiv spiritual consistory, Kyiv city 1700-1930 [in Ukrainian and in Russian].

Стаття надійшла до редакизї 14.02.2019 p.

УДК 788.5 “17”

Срмак Ігор Юрійович, аспірант кафедри старовинної музики Національної музичної академії України ім. П.І. Чайковського ORCID 0000-0002-3695-8822 Igoriermak@gmail.com

\title{
РИТМІЧНА АЛЬТЕРАЦІЯ У ФЛЕЙТОВОМУ ВИКОНАВСЬКОМУ МИСТЕЦТВІ ХVІІ СТОЛІТТЯ
}

Мета роботи. Розглянути специфіку виконання ритму у флейтовій музиці XVIII ст. Систематизувати вказівки і правила $з$ флейтових трактатів цього періоду (Ж.-М. Оттетер /1707/, М. Корретт /1740/, Й. Й. Кванц /1752/, К.Ф.Е. Бах /1753/, Т. Борде /1755/, Й.Г. Тромліц /1791/). Методологія. У статті застосовано джерелознавчий, історичний, аналітичний та виконавський методи дослідження. Наукова новизна. Вперше у вітчизняному музикознавстві систематизовано основні правила роботи з ритмом, що подані у старовинних трактатах для флейти. Це дає змогу побачити динаміку розвитку поглядів на проблему ритмічної альтерації у флейтовому виконавському мистецтві XVIII ст. і застосувати набуті знання у педагогічній і концертній діяльності. Висновки. У XVIII ст. існувала традиція виконання ритму інакше, аніж він був зафіксований в нотному тексті. Найрізноманітніші випадки ритмічних альтерацій можна умовно поділити на три групи: поtеs inégales, загострення пунктиру (т. зв. “ритм французької увертюри”) та співвідношення пунктирного i тріольного ритмів у різних голосах. Тогочасні флейтові трактати містять рекомендації і правила щодо їхнього правильного прочитання. Основним орієнтиром у пошуку адекватної метроритмічної моделі $є$ характер й афект твору. Також мусить бути врахована специфіка флейти як духового інструмента.

Ключові слова: ритм; ритмічна альтерація; notes inégales; ритм французької увертюри; флейтове виконавське мистецтво; музичне мистецтво XVIII ст.

Ермак Игорь Юрьевич, аспирант кафедры старинной музыки Национальной музыкальной академии Украины им. П.И. Чайковского

Ритмическая альтерация во флейтовом исполнительском искусстве XVIII века

Цель работы. Рассмотреть специфику исполнения ритма во флейтовой музыке XVIII в. Систематизировать указания и правила из флейтовых трактатов этого периода (Ж.-М. Оттетер /1707/, М. Корретт /1740/, И.И. Кванц /1752/, К.Ф.Э. Бах /1753/, Т. Борде /1755/, И.Г. Тромлиц /1791/). Методология. В статье применены источниковедческий, исторический, аналитический и исполнительный методы исследования. Научная новизна. Впервые в отечественном музыковедении систематизированы основные правила работы с ритмом, представленные в старинных трактатах для флейты. Это позволяет увидеть динамику развития взглядов на проблему ритмичной альтерации во флейтовом исполнительском искусстве XVIII в. и применить полученные знания в педагогической и концертной деятельности. Выводы. В XVIII в. существовала традиция исполнения ритма иначе, чем он был зафиксирован в нотном тексте. Разнообразнейшие случаи ритмических альтераций можно условно разделить на три группы: notes inégales, обострение пунктира (т.н. "ритм французской увертюры”) и соотношение пунктирного и триольного ритмов в разных голосах. Тогдашние флейтовые трактаты содержат рекомендации и правила их правильного прочтения. Основным ориентиром в поиске адекватной метроритмической модели является характер и аффект произведения. Также должна быть учтена специфика флейты как духового инструмента.

Ключевые слова: ритм; ритмическая альтерация; notes inégales; ритм французской увертюры; флейтовое исполнительское искусство; музыкальное искусство XVIII в.

(C) Єрмак I. Ю., 2019 
Yermak Ihor, postgraduate student of the department of ancient music, National Music Academy of Ukraine named after P. I. Tchaikovsky

Rhythmic alteration in the flute performing art of the 18th century

Purpose of the article. Consider the specifics of the performance of rhythm in flute music of the 18th century. Systematize instructions and rules from flute treatises of this period (J.-M. Hotteterre /1707/, M. Corrette /1740/, J.J. Quantz /1752/, C.P.E. Bach /1753/, T. Borde /1755/, J.G. Tromlitz /1791/). Methodology. The article applies source study, historical, analytical and performing research methods. Scientific novelty. For the first time in domestic musicology, the basic rules for working with rhythm, presented in ancient flute treatises, are systematized. This allows us to see the dynamics of the development of views on the problem of rhythmic alteration in the flute performing art of the 18th century and apply this knowledge in pedagogical and concert activities. Conclusions. In the 18th century there was a tradition of performing the rhythm differently than it was written in a musical text. The most diverse cases of rhythmic alterations can be divided into three groups: notes inégales, over-dotting (the so-called "rhythm of the French overture") and the juxtaposition of dotted rhythms and triplets. Flute treatises of the time contain recommendations and rules for their proper reading. The main guideline in finding an adequate metro-rhythmic model is the mood and affect of the work. The specifics of the flute as a wind instrument should also be taken into account.

Key words: rhythm; rhythmic alteration; notes inégales; the rhythm of the French overture; flute performing arts; musical art of the 18 th century.

Сучасний музикант звик максимально точно виконувати виписаний ритм, адже із самого дитинства його вчать правильно визначати найрізноманітніші ритмічні малюнки, зіставляти їх між собою. У разі виникнення особливих складнощів на допомогу виконавцеві завжди приходить комп’ютерна техніка, яка дає змогу абсолютно точно зіставити, наприклад, дуоль 3 тріоллю, квартоль 3 квінтоллю та навіть септоль 3 нонемоллю. Сформувавшись у середовищі такої математичної стерильності ритму, нам важко навіть уявити, що беззаперечне слідування нотному тексту далеко не завжди було обов'язковою вимогою до музиканта. Більше того, були часи, коли точне виконання виписаних тривалостей вважалося ознакою поганого смаку.

У музиці XVIII ст. нотація ритму часто не відображала його реалізацію у виконанні: виписані ноти рівної тривалості могли виконуватися нерівно, пунктир міг загострюватися, а затакт звужуватись. У сучасному західному музикознавстві всі ці види ритмічних змін отримали загальну назву - "ритмічні альтераиії".

Актуальність теми дослідження полягає в тому, що в сучасних умовах розвитку історичноінформованого виконавства знання особливостей виконавського мистецтва XVIII ст., до яких належить і стилістично грамотне виконання ритму, має дуже велике значення і відіграє важливу роль як у теоретичному, так і у практичному аспектах.

Аналіз досліджень і публікацій. Проблема точності прочитання і виконання ритму у старовинній музиці на даний момент висвітлена у багатьох зарубіжних $[7,144-149 ; 10,83-86 ; 14,42$ $66 ; 8,42-45 ; 17,136-157 ; 16,64-67 ; 13,53-87]$ і в деяких вітчизняних музикознавчих працях [6, 16$17 ; 2,127-128]$. Щодо дерев'яних духових інструментів, найбільш повно особливості ритмічної альтерації розглянуті в докторській дисертації Т. Е. Ворнера (1964 р.) [17, 136-157]. Він простежує історію розвитку практики альтерації виписаного ритму від її виникнення (з часів григоріанського співу) і аж до початку XIX ст. Багато уваги питанню ритмічної альтерації у флейтовому виконавстві епохи бароко у своїй кандидатській дисертації приділяє Ю.В. Шелудякова [7, 144-149], спираючись переважно на трактат Й. Й. Кванца і книгу Р. Донінгтона [14].

Стаття базується на інформації 3 теоретичних трактатів видатних музикантів-флейтистів XVIII ст., де містяться відомості щодо принципів застосування ритмічної альтерації у виконавській практиці цього періоду. Основою для нашого дослідження послужили праці Ж.-М. Оттетера (1707, 1719) [5, 40-76; 15], М. Корретта (1740) [11], Й. Й. Кванца (1752) [3], К. Ф. Е. Баха (1753) [1], Т. Борде (1755) [9] і Й.Г. Тромліца (1791) [5, 81-371].

Мета дослідження - у хронологічному порядку представити правила роботи з ритмом у музиці XVIII ст.

Виклад основного матеріалу. Найрізноманітніші випадки ритмічної альтерації у флейтовій музиці XVIII ст. можна умовно поділити на три основні групи: нерівні ноти (notes inégales), загострення пунктирного ритму (т.зв. “ритм франиузької увертюри”) і співвіднотення пунктирного і тріольного ритмів в різних голосах. Їхнє трактування в кожному конкретному випадку залежить від стильової приналежності твору і загального контексту. Розглянемо це.

Notes inégales. У музиці (найчастіше - французькій) всього XVIII ст. була розповсюджена традиція нерівного виконання домінуючих швидких тривалостей, що рухались поступово. Інформація про це подана в численних трактатах того часу, написаних для різних інструментів. Щодо 
флейтового виконавства, то відомості про notes inégales здебільшого сконцентровані у працях Ж.М. Оттетера, М. Корретта, Й.Й. Кванца, Т. Борде, Г. Тромліца. Ми розглянемо окремо кожен з цих трактатів і виділимо основні правила виконання і застосування ритмічної нерівності.

Виконання notes inégales на флейті нерозривно пов'язане 3 коротким i довгим артикуляційними складами $t u r u$. Підтвердження цього знаходимо у 8-му розділі «Основ...» Ж.-М. Оттетера (1707). Автор наводить приклад, де м'який і довгий склад ru припадає на хороші ноти(довгі, сильні, ударні), які у такий спосіб подовжуються, а чіткий і короткий $t и$ - на поганi (короткі, слабкі, неударні), які стають більш короткими у співвідношенні з попередніми $[5,59]$. Також у своїй праці 3 прелюдування він наголошує, що всі вісімки у прелюдіях, представлених ним, повинні виконуватись нерівно, якщо немає авторської ремарки про протилежний спосіб виконання $[15,6]$. Цікаво, що $\mathrm{i}$ флейтист Оттетер, і клавесиніст Ф. Куперен («Мистецтво гри на клавесині», 1716 р.) [4, 29] приблизно в один період говорять про нерівне виконання тільки вісімок, тоді як автори пізніших трактатів пишуть про застосування inégal щодо найкоротших тривалостей твору (якими часто $\epsilon$ шістнадцятки).

Пізніше М. Корретт у 5-му розділі своєї «Методи...» (1740) для флейти інструктує стосовно використання рівних і нерівних нот у певних розмірах і частинах творів. На відміну від Оттетера $\mathrm{i}$ Кванца, він не пов'язує inégal з артикуляцією, зокрема із використанням короткого і довгого складів $t u r u$, адже у своїй методі взагалі відмовляється від них і радить користуватися лише односкладовою артикуляцією $[11,20]$. Цікаво, що його правила стосуються творів - представників різних національних стилів (переважно, французького й італійського) [11, 4-6]:

1. У чотиридольних розмірах $\mathbf{C}$ i $\square$, що часто використовуються в італійській музиці в Allemande, Adagio, Allegro i Presto (частинах сонат і концертів), вісімки виконуються рівно, а шістнадцятки - нерівно. Інколи в частинах Allegro і Presto шістнадцятки можуть виконуватись рівно.

2. У дводольному розмірі 2, що використовується у французькій музиці (і дуже рідко в італійській) для ригодонів, гавотів, буре і котильйонів, вісімки у групах по дві ноти виконуються нерівно (пунктирно).

3. У концертів, вісімки виконуються рівно, шістнадцятки - пунктирно. Іноді в сонатах шістнадцятки можуть виконуватись рівно.

4. Розмір $3 / 2$ позначає повільний темп і часто використовується у сарабандах. Чвертки в цьому розмірі повинні бути зіграні нерівно. Однак характер п'єси може стати орієнтиром i для їх рівного виконання.

5. Восьмі виконуються рівно, а шістнадцятки - нерівно у розмірі $3 / 8$, який у французькій музиці використовується для nacn' $\epsilon$, а також для affettuoso, менуетів і allegro в сонатах.

6. Розмір \% використовується у лурі (французький стиль), водевілях і контрдансах (англійський стиль), зрідка зустрічається в італійській музиці. Чверті в ньому необхідно акцентувати, а восьмі виконувати inégale.

7. Для жиг у французькому та італійському стилях використовується розмір \%. Вісімки завжди виконуються рівно (про шістнадцятки Корретт не згадує, отож можна припустити, що вони також мали бути рівними), перші дві часто зліговуються, третя артикулюється (можливе також лігування по 3 вісімки).

8. Розмір $9 / 8$ часто зустрічається у італійських жсигаx, allegro і presto (у французькій музиці використовується тільки зрідка). Вісімки - égale, шістнадцятки - inégale.

9. Для жиг у італійській, французькій, німецькій i англійській музиці може бути використаний розмір 12 . Вісімки виконуються рівно, а шістнадцятки - пунктирно.

Отже, в деяких випадках Корретт допускає винятки з огляду на характер твору.

Підтвердження безпосереднього зв'язку артикуляції та ритму знаходимо у «Досвіді...» Й. Й. Кванца (1752). Він пише, що двоскладова структура tiri «...найбільше підходить для не дуже жвавих пасажів, особливо тому, що навіть найшвидші ноти в них завжди варто грати трохи неоднаково [курсив наш - I.C.]» [3,74]. Далі він констатує, що в цій артикуляційній структурі наголос припадає на другий склад $r i$, який завжди довший за ненаголошений $t i$ і використовується на сильній долі, а «в групі з чотирьох шістнадцяток $r i$ завжди буде попадати на першу і третю ноти, а $t i-$ на другу і четверту» $[3,74]$.

Кванц пише, що у поступовому русі варто розрізняти головні (основні, хороші) ноти, які необхідно «підкреслювати рухами грудної клітки» $[3,127]$ трохи подовжуючи, і виконуючи голосніше, і прохідні (погані), що виконуються слабше. «Згідно з цим правилом, навіть найкоротші ноти в кожній п'єсі стриманого темпу чи в Adagio, не зважаючи на те, що вони записані однаковими 
тривалостями, повинні виконуватись трохи нерівно, так щоб ударні ноти кожної фігури, а саме перша, третя, п'ята і сьома, затримувались трохи довше, ніж прохідні - друга, четверта, шоста i восьма», важливо, що «подібне подовження ноти не повинно бути рівним по тривалості ноті 3 крапкою» $[3,121]$. До коротких нот німецький флейтист відносить чверті в такті на $3 / 2$, вісімки в такті на $3 / 4$ і шістнадцятки в такті на $3 / 8$, а також восьмі в alla breve і шістнадцятки чи тридцять другі в такті на $2 / 4$ або в простому парному розмірі. Якщо з'являються фігури 3 тривалостями вдвічі коротшими за ті, на яких виконувалась нерівність, то тоді саме їх необхідно починати виконувати в описаній манері. Винятком для інструменталістів $\epsilon: a)$ пасажі в дуже швидких темпах, де неможливо встигнути виділити всі необхідні ноти, отож, лише перша з чотирьох нот виконується довше і голосніше; б) ноти, які мають штрихові позначення; в) кілька нот однієї висоти, що йдуть одна за одною; г) чотири, шість чи вісім нот, з'єднані лігою; $t$ ) восьмі в жигах.

Про традицію виконання нерівних нот згадує і французький флейтист Т. Борде у своїй «Meтодi...» (1755). Автор пише, що у разі відсутності будь-яких позначень над рівними за тривалістю нотами, вони, за традицією, повинні виконуватися трохи нерівно (inégale). Крапка ж над нотою вказує на ритмічно рівне (égale) виконання $[9,5]$, на відміну від звичного для нас трактування крапки як штриха staccato. У розмірах $\mathrm{C}, 3 / 8,2 / 4,6 / 8,9 / 8,{ }^{12} / 8$ i ${ }^{2} / 8$, за Борде, завжди треба грати рівно. У всіх інших випадках нерівність переходить 3 більших до менших тривалостей, що з'являються у п'єсі. Наприклад, якщо спочатку рух йде чвертками і вони граються inégale, то в разі появі восьмих, нерівно необхідно грати вже їх, а чвертки виконувати égale до вступу коротших тривалостей $[9,8]$.

Наприкінці століття - 1791 р. - до проблеми сильних і слабких нот в контексті ритмічної нерівності звернувся Г. Тромліц. Як Оттетер і Кванц, Тромліц пов'язує виконання notes inégales на флейті з артикуляційними фонемами. Для ударних нот - це, залежно від обставин, $d a$ або $r a$, для неударних - ta (винятком є перша нота фрази, яка є сильною, але завжди виконується на $t a$ ). Правила Тромліца співвідносяться з основами використання артикуляції для ритмічної нерівності, описаними Кванцем. Проте інколи у плавному русі вісімками Тромліц використовує після $t a$, $d a$, ra замість інших складів лише голосну $a$ (без приголосних). Така артикуляція максимально пом'якшує слабкі ноти і фактично створює ефект legato.

Причиною того, чому notes inégales так і не отримали сталого позначення в нотації, найвірогідніше $\epsilon$ величезне розмаїття можливих варіантів нерівності, яка, в залежності від характеру твору, могла коливатись від майже пунктиру (у числовому співвідношенні $3: 1$ ), до ледь помітної нерівності (4:3) [10,83].

До сьогоднішнього часу питання необхідності застосування notes inégales в тій чи іншій музиці залишається вирішеним не до кінця. Спираючись на те, що дана традиція згадується у багатьох виконавських трактатах (причому не тільки флейтових) саме французьких авторів $\mathrm{i}$ характерна передусім для французького стилю, можна припустити, що використовувати нерівність у музиці, яка написана в інших національних стилях, слід з обережністю. Однак, повністю відкидати можливість застосування notes inégales у нефранцузькій музиці не можна, оскільки про це пишуть Корретт, Кванц і Тромліц, а також з огляду на інтенсивний стильовий взаємообмін, що мав місце у XVIII ст., та становлення мішаного стилю. Зауважимо, однак, що основним орієнтиром для виконавця завжди повинен залишатися характер конкретного твору. Зважаючи на те, що дана манера гри згадується у трактатах всього XVIII ст., використання іiї буде доречним як у творах епохи Бароко, так і в музиці галантного і класичного стилів.

Загострення пунктирного ритму. Як рівні за тривалістю ноти могли виконуватись нерівно, так і виписана нерівність, тобто пунктирний ритм, найчастіше виконувалася трохи відмінно від записаного. Ноту з крапкою музикант мав акцентувати, а наступну одну чи кілька нот грати гостріше і швидше ніж записано. Такий вид ритмічної альтерації сформувався у попередньому - XVII столітті у творчості французьких композиторів, зокрема в операх Ж.-Б. Люллі, завдяки чому отримав назву "ритм французької увертюри". Він став надзвичайно затребуваним завдяки своїй виразності підкресленому, енергійному спрямуванню слабкого (ямбічного, затактового) елементу до сильної долі. У флейтових трактатах до питання загострення пунктирного ритму звертаються Й.Й. Кванц та Г. Тромліц.

Й. Й. Кванц, пояснюючи правильне виконання тривалостей нот, зауважує, що нота 3 крапкою повинна триматися довше за іiі виписану тривалість, а та що слідує за нею - скорочуватись (приклад $1)$. 


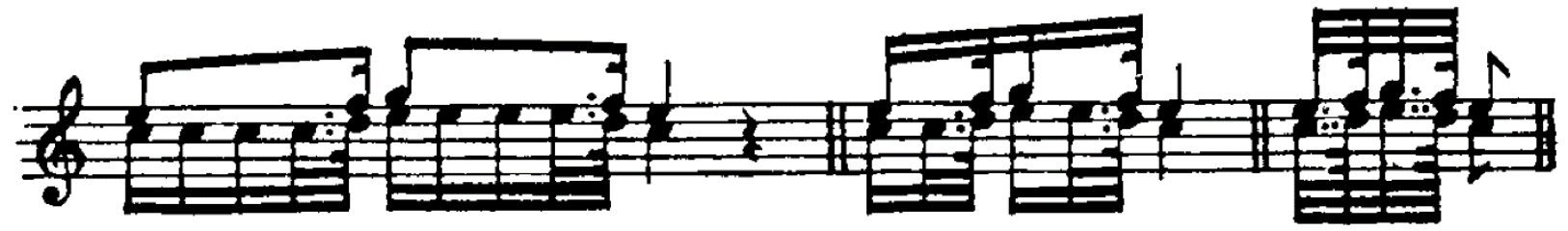

Приклад1. Й.Й. Кванщ. Загострення пунктирного ритму [3, 67].

Вдруге Кванц повертається до теми ритмічного загострення при поясненні особливостей виконання популярних танців XVIII ст. За його словами, у розмірах $2, \square, 3 / 4$ у лурі, сарабандi, куранті і чаконі «вісімки, що стоять за чвертками $з$ крапкою, слід грати не з їх точною тривалістю, а дуже коротко і гостро» [3,284]. Також, за Кванцем, три і більше тридцять других, що йдуть після нот 3 крапкою або пауз, краще виконувати якомога швидше, в останній момент перед наступною долею. Особливо яскравий ефект ритмічне загострення має у повільних п’єсах [3, 284].

Ритмічна альтерація згадується і наприкінці XVIII ст. Багато уваги приділяє цьому питанню Й. Г. Тромліц у своїх «Настановах» (1791). Для автора трактату, хороше виконання пунктирного ритму - це перетримання ноти 3 крапкою, ніби вона має дві крапки, і скорочення тривалості наступних нот [5, 230-231]. Більш того, німецький флейтист пропонує ще гостріший варіант ритмічної альтерації, коли ноту з крапкою необхідно тримати до наступної долі, а в момент іiі настання зіграти другу, коротку ноту [5, 231].

Якщо після ноти з крапкою слідує не одна а декілька нот ритм також загострюється, при чому швидкі ноти необхідно зв'язувати з попередньою нотою лігою і не артикулювати окремо (приклад 2).

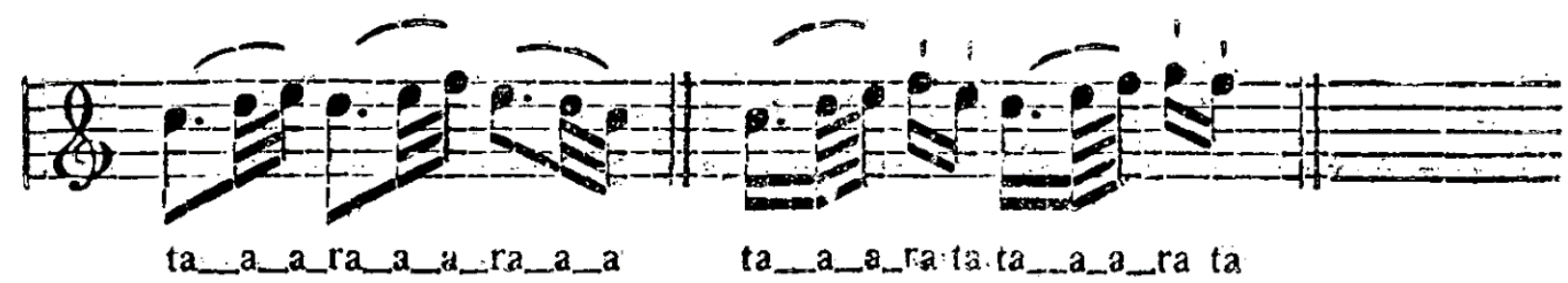

Приклад 2. Й.Г. Тромліц. Лігування при пунктирному ритмі [5, 231].

Аналогічне загострення застосовувалося і до зворотного пунктиру. Судячи 3 прикладів Тромліца, короткі ноти в такому випадку також завжди лігувалися з довгою (приклад 3 ).

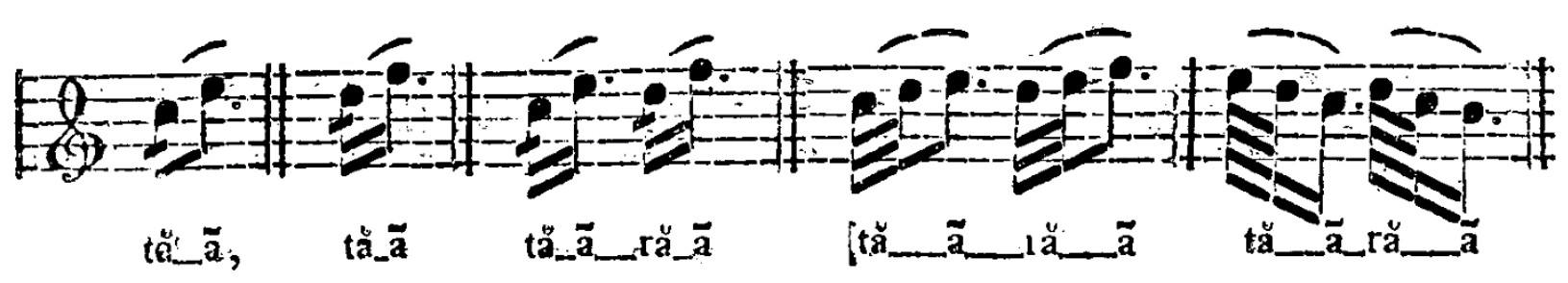

Приклад 3. Й.Г. Тромліц. Лігування при оберненопунктирному ритмі [5, 232].

У повільних темпах ритмічна альтерація посилюється ще більше, але, в той самий час, альтеровані ноти виконуються м'якше і ніжніше [5, 232].

На перший погляд, правила Тромліца для пунктирного ритму абсолютно незмінні для усі випадків, адже він не пропонує рівності виконання, як альтернативи ритмічній альтерації. Однак останній абзац восьмої глави, де обговорюється пунктирний ритм, переконує в протилежному. У ньому автор пропонує композиторам диференціювати пунктир з одною і двома крапками, адже у протилежному випадку музикант може спиратися тільки на свою «розсудливу інтуїцію» $[5,232]$. Інакше кажучи, правильний вибір залежав, перш за все, від характеру та афекту твору і залишався за виконавцем. Пам'ятаймо, що за традицією епохи це було справедливо також і щодо багатьох інших складових виконавської інтерпретації.

Співвідношення пунктирного $i$ тріольного ритмів. Ще однією проблемою, пов'язаною 3 ритмом в музиці XVIII ст., $є$ співвідношення пунктиру в одному голосі 3 тріолями в іншому. Першим 
висвітлював це питання Й. Й. Кванц, який протиставляв квартолі і тріолі. За його словами, швидку ноту з пунктирної комбінації слід виконувати після третьої ноти тріолі з іншого голосу, а не разом 3 нею, у протилежному випадку «мелодія, замість того, щоб прозвучати велично і яскраво, стане млявою і нудною» $[3,67]$. К. Ф. Е. Бах дотримується протилежної думки і вважає правильним синхронізацію другої ноти пунктиру з третьою нотою тріолі $[1,110-111]$. Тромліц згадує про обидва способи виконання швидкої ноти пунктиру: разом з третьою нотою тріолі і після неї. Теоретично вірним він вважає саме другий варіант (Кванц), однак, на його думку, таке співвідношення ритмів створює неналежний ефект $[5,164]$.

Отже, історичні документи свідчать: думки теоретиків XVIII ст. щодо правильного виконання вищезазначених ритмічних співвідношень розходились, що в багатьох випадках дозволяє залишити вирішення цієї проблеми на розсуд музиканта.

Наукова новизна. У дослідженні вперше у вітчизняному музикознавстві в хронологічному порядку представлено основні правила роботи з ритмом, що подані у старовинних трактатах. Це дає змогу простежити динаміку розвитку поглядів на проблему ритмічної альтерації у флейтовому виконавському мистецтві XVIII ст. і використати здобуті знання у педагогічній і концертній діяльності.

Висновки. Ритм є однією з основних складових музичної тканини. У XVIII ст. правила роботи з ритмом відрізнялися від сучасних і допускали значну свободу виконавського трактування, що було описано в історичних джерелах. Видами ритмічної альтерації у XVIII ст. були нерівні ноти (notes inégales), загострення пунктирного ритму (ритм французької увертюри) i співвідношення пунктирного і тріольного ритмів. Знання і використання рекомендацій і правил, поданих у трактатах XVIII ст. і систематизованих в даному дослідженні, $\epsilon$ необхідною умовою для історично обгрунтованого і художньо яскравого виконання старовинних творів.

\section{Примітки}

${ }^{1}$ У переважній більшості англійських трактатів першої половини та середини XVIII ст. подаються ідентичні відомості щодо notes inégales, адже до 1766 p. (рік виходу праці Л. Гренома) всі англійські автори видавали переклади «Основ» Оттетера, копіюючи їх в тій чи іншій мірі.

${ }^{2}$ Прикладом такої п’єси, за Корреттом, може бути англійська арія «Dulty miller» $[11,5]$.

3 Аналогічну думку висловлює і К.Ф.Е. Бах у своєму «Досвіді...» (1753). Однак, він зауважує, що це правило має певні винятки. Наприклад, якщо на пунктирній фігурі проставлена трель або групето, їх варто виконувати ширше. Схожа ситуація і в сумних або виразних темах. Також пунктир, за Бахом, не виконується занадто швидко у повільних темпах $[1,109]$.

${ }^{4}$ Гарним наочним прикладом $є$ перша частина відомої сонати a-moll для рекордера i basso continuo (HWV 362) Г.Ф. Генделя.

\section{Лimepamypa}

1. Бах К. Ф. Э. Опыт истинного искусства клавирной игры. Санкт-Петербург: EARLYMUSIC PUBLISHING HOUSE, $2005.170 \mathrm{c}$.

2. Качмарчик В.П. Немецкое флейтовое искусство XVIII-XIX вв. Донецк: Юго-Восток, 2008. 310 c.

3. Кванц И.И. Опыт наставления в игре на флейте траверсо. Санкт-Петербург: EARLYMUSIC PUBLISHING HOUSE, 2013. $387 \mathrm{c}$.

4. Куперен Ф. Искусство игры на клавесине. Ф. Куперен. Москва: Музыка, 1973. 152 с.

5. Хазанов Н.И. Старинные трактаты об искусстве игры на флейте: С. Ганасси, Ж.-М. Оттетер, И.Г. Тромлиц. Диссертация на соискание ученой степени кандидата искусствоведения. Москва, 2009. 423 с.

6. Шабалтина С.М. Клавесин сквозь века. Заметки исполнителя. Киев: Український пріоритет, 2013. $160 \mathrm{c}$.

7. Шелудякова Ю.В. Национальные стили и исполнительские традиции флейтовой музыки эпохи бароко. Диссертация на соискание ученой степени кандидата искусствоведения. Тамбов, 2008. 244 с.

8. Boland J.D. Method for the one-keyed flute. Berkeley: University of California Press, 1998. 224 p.

9. Bordet T. Méthode raisonnée pour apprendre la musique [Електронний ресурc] URL: https://imslp.nl/imglnks/usimg/5/56/IMSLP314824-PMLP508545-Bordet,_Toussaint_-

_M\%C3\%A9thode_raisonn\%C3\%A9e_pour_apprendre_la_musique_(1755).pdf

10. Brown R. The early flute: a practical guide. New York: Cambridge University Press, 2002. 179 p.

11. Corrette Michel, Méthode pour apprendre à jouër la flûtte [Електронний pecypc] URL: https://imslp.nl/imglnks/usimg/f/fe/IMSLP285215-PMLP462950-corrette_methode_flute.pdf

12. Crown H. Lewis Granom: his significance for the flute in the eighteenth century. Dissertation for the degree of Doctor of Philosophy. Cardiff, 2013. 237 p.

13. Dolmetsch A. The Interpretation of the Music of the 17th and 18th Centuries. London: Novello and Company, 1946. 493 p. 
14. Donington R. Baroque music: style and performance. New York: W.W. Norton \& Company, 1982. 206 p.

15. Hottererre Jacques Martin, L'art de Preluder sur la Flûte Traversiere, Sur la Flûte-a-bec, Sur le Haubois et autre Instruments de Dessus [Електронний ресурc] URL: http://hz.imslp.info/files/imglnks/usimg/8/81/IMSLP346604PMLP124167-hotteterre_principes_op1.pdf

16. Lawson C., Stowell R. The historical performance of music: an introduction. New York: Cambridge University Press, 1999. 219 p.

17. Warner T. E. Indications of performance practice in woodwind instruction books of the 17th and 18th centuries. Dissertation for the degree of Doctor of Philosophy. New York, 1964. 459 p.

\section{References}

1. Bach C.P.E. (2005). Opyt istinnogo iskusstva klavirnoi igry. Saint Petersburg: EARLYMUSIC PUBLISHING HOUSE [in Russian]. Russian].

2. Kachmarchik V.P. (2008). Nemetskoe fleitovoe iskusstvo XVIII-XIX vv. Donetsk: Yugo-Vostok [in

3. Quantz J.J. (2013). Opyt nastavleniia v igre na fleite traverso. Saint Petersburg: EARLYMUSIC PUBLISHING HOUSE [in Russian].

4. Couperin F. (1973). Iskusstvo igry na klavesine. Moskva: Muzyka [in Russian].

5. Khazanov N.I. (2009). Starinnye traktaty ob iskusstve igry na fleite: S.Ganassi, Zh.-M. Otteter, I.G. Tromlits. Candidate's thesis. Moscow [in Russian]. Russian].

6. Shabaltina S.M. (2013). Klavesin skvoz veka. Zametki ispolnitelya. Kyiv: Ukrajinsjkyj prioritet [in

7. Sheludiakova Yu.V. (2008). Natsionalniie stili i ispolnitelskiie traditsii fleitovoi muzyki epokhi barokko. Candidate's thesis. Tambov [in Russian].

8. Boland J.D. (1998). Method for the one-keyed flute. Berkeley: University of California Press [in English].

9. Bordet Toussaint, Méthode raisonnée pour apprendre la musique. Retrieved from: https://imslp.nl/imglnks/usimg/5/56/IMSLP314824-PMLP508545-Bordet,_Toussaint_-

_M\%C3\%A9thode_raisonn\%C3\%A9e_pour_apprendre_la_musique_(1755).pdf [in French].

10. Brown R. (2002). The early flute: a practical guide. New York: Cambridge University Press [in English].

11. Corrette Michel, Méthode pour apprendre à jouër la flûtte. Retrieved from: https://imslp.nl/imglnks/usimg/f/fe/IMSLP285215-PMLP462950-corrette_methode_flute.pdf [in French].

12. Crown H. (2013). Lewis Granom: his significance for the flute in the eighteenth century. Candidate's thesis. Cardiff [in English].

13. Dolmetsch A. (1946). The Interpretation of the Music of the 17th and 18th Centuries. London: Novello and Company [in English]. English].

14. Donington R. (1982). Baroque music: style and performance. New York: W.W. Norton \& Company [in

15. Hottererre Jacques Martin, L'art de Preluder sur la Flûte Traversiere, Sur la Flûte-a-bec, Sur le Haubois et autre Instruments de Dessus. Retrieved from: http://hz.imslp.info/files/imglnks/usimg/8/81/IMSLP346604PMLP124167-hotteterre_principes_op1.pdf [in French].

16. Lawson C., Stowell R. (1999). The historical performance of music: an introduction. New York, USA: Cambridge University Press [in English].

17. Warner T. E. (1964). Indications of performance practice in woodwind instruction books of the 17 th and 18th centuries. Doctor's thesis. New York [in English].

Стаття надійшла до редакиії 22.12.2018 p. 